\title{
Aortic annuloplasty: The panacea of valve-preserving aortic replacement?
}

\author{
Hans-Joachim Schäfers, MD
}

\footnotetext{
From the Department of Thoracic and Cardiovascular Surgery, Saarland University Medical Center, Homburg/ Saar, Germany.

Disclosures: Author has nothing to disclose with regard to commercial support.

Received for publication Jan 10, 2017; accepted for publication Jan 12, 2017; available ahead of print Feb 22 , 2017.

Address for reprints: Hans-Joachim Schäfers, MD, Department of Thoracic and Cardiovascular Surgery, Saarland University Medical Center, Homburg/Saar, Germany (E-mail: h-j.schaefers@uks.eu).

J Thorac Cardiovasc Surg 2017;153:1043-4

$0022-5223 / \$ 36.00$

Copyright (c) 2017 by The American Association for Thoracic Surgery

http://dx.doi.org/10.1016/j.jtcvs.2017.01.024
}

In the early 1990s, 2 methods of valve-preserving aortic replacement were developed and proposed: root remodeling $^{1}$ and valve reimplantation. ${ }^{2}$ Later publications showed apparently better stabilization of aortic valve function after reimplantation ${ }^{3,4}$ The difference was attributed to better annular stabilization with reimplantation, and reimplantation became the preferred approach for the majority of surgeons.

The apparent importance of annular stabilization also led Lansac and coworkers ${ }^{5,6}$ to introduce the combination of remodeling with a circular annuloplasty, indicating that annuloplasty is the answer to a shortcoming of root remodeling. ${ }^{6}$ These observations, however, could also be interpreted as confirmation of the principle of annular stabilization proposed by David and Feindel. ${ }^{2}$

In their current article in this issue of the Journal, Lansac and collagues ${ }^{7}$ have analyzed the midterm results of this latter approach in a large series. The results are good: despite the fact that almost $70 \%$ required some cusp intervention, excellent functional results were obtained with good stability. This series thus compares favorably with others. As emphasized previously, annuloplasty was the main modification relative to the traditional approach. ${ }^{1}$ At a closer look, there were in fact 2 modifications introduced at similar time, an annuloplasty and-even though it is not listed in the title-the application of intraoperative measurement of cusp configuration ${ }^{8}$ to achieve a predictable valve configuration.

Is this report definite proof that the annulus must be stabilized to achieve durable aortic valve function after valve-preserving surgery? The answer is not as easy as it looks at first sight. The addition of an annuloplasty appears reasonable in principle if one extrapolates the experience from mitral repair to the aortic valve. The addition of annuloplasty has definitely been shown to improve durability after aortic valve repair. ${ }^{9}$ On the other hand, the results of the current study of Lansac and collagues ${ }^{7}$ are not unequivocal, because 2 parameters were changed at almost the same time. It is thus impossible to discriminate

\section{References}

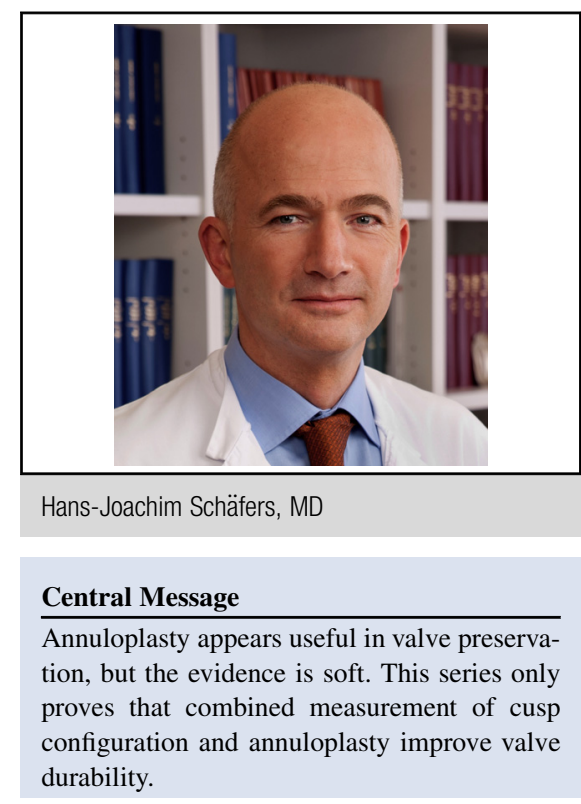

See Article page 1033 .

whether the improvement in results was due to annuloplasty or rather to the standardized method of assessing cusp configuration. $^{8}$ Possibly both aspects are important, and this emphasizes that valve-sparing aortic replacement should be considered as an aortic valve repair procedure.

Finally, despite theoretic advantages of an annuloplasty, some questions remain. There is no effective surgical intervention that does not have side effects, and the potential risks of this addition are uncertain. In addition, it would seem more appropriate to adjust the sizing of the annuloplasty to the size of the patient and the aortic cusps.

At this time, Lansac and collagues ${ }^{7}$ are to be congratulated for their continued efforts to develop and refine annuloplasty for valve-preserving aortic surgery. Nonetheless it may be useful to retain a certain degree of critical attitude while trying to achieve clear and unambiguous proof of the benefits of annuloplasty. Apart from improvement in early valve competence, my own group has not yet seen a documented long-term advantage with the addition of our form of annuloplasty. ${ }^{10,11}$

1. Sarsam MA, Yacoub M. Remodeling of the aortic valve anulus. J Thorac Cardiovasc Surg. 1993;105:435-8.

2. David TE, Feindel CM. An aortic valve-sparing operation for patients with aortic incompetence and aneurysm of the ascending aorta. J Thorac Cardiovasc Surg. 1992;103:617-21; discussion 622. 
3. Yacoub MH, Gehle P, Chandrasekaran V, Birks EJ, Child A, RadleySmith R. Late results of a valve-preserving operation in patients with aneurysms of the ascending aorta and root. J Thorac Cardiovasc Surg. 1998;115:1080-90.

4. David TE, Feindel CM, David CM, Manlhiot C. A quarter of a century of experience with aortic valve-sparing operations. J Thorac Cardiovasc Surg. 2014; 148:872-9; discussion 879-80.

5. Lansac E, Di Centa I, Bonnet N, Leprince P, Rama A, Acar C, et al. Aortic prosthetic ring annuloplasty: a useful adjunct to a standardized aortic valve-sparing procedure? Eur J Cardiothorac Surg. 2006;29:537-44.

6. Lansac E, Di Centa I, Sleilaty G, Crozat EA, Bouchot O, Hacini R, et al. An aortic ring: from physiologic reconstruction of the root to a standardized approach for aortic valve repair. J Thorac Cardiovasc Surg. 2010;140 (6 Suppl):S28-35; discussion S45-51.
7. Lansac E, Di Centa I, Sleilaty G, Lejeune S, Berrebi A, Zacek P, et al. Remodeling root repair with an external aortic ring annuloplasty. J Thorac Cardiovasc Surg. 2017;153:1033-42.

8. Schäfers HJ, Bierbach B, Aicher D. A new approach to the assessment of aortic cusp geometry. J Thorac Cardiovasc Surg. 2006;132:436-8.

9. Schneider U, Hofmann C, Aicher D, Takahashi H, Miura Y, Schäfers HJ, et al. Suture annuloplasty significantly improves the durability of bicuspid aortic valve repair. Ann Thorac Surg. 2017;103:504-10.

10. Kunihara T, Aicher D, Rodionycheva S, Groesdonk HV, Langer F, Sata F, et al. Preoperative aortic root geometry and postoperative cusp configuration primarily determine long-term outcome after valve-preserving aortic root repair. $J$ Thorac Cardiovasc Surg. 2012;143:1389-95.

11. Schäfers HJ, Raddatz A, Schmied W, Takahashi H, Miura Y, Kunihara T, et al. Reexamining remodeling. J Thorac Cardiovasc Surg. 2015;149(2 Suppl):S30-6. 